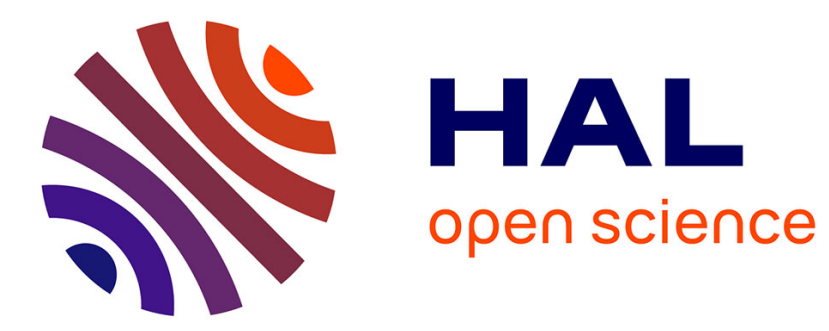

\title{
Low Temperature Plasma Nitriding of Low Alloy Steel for the Enhancement of Hardness
}

K. Ram Mohan Rao, Corinne Nouveau, K. Trinadh

\section{To cite this version:}

K. Ram Mohan Rao, Corinne Nouveau, K. Trinadh. Low Temperature Plasma Nitriding of Low Alloy Steel for the Enhancement of Hardness. Materials Today: Proceedings, 2019, 17, pp.26-33. 10.1016/j.matpr.2019.06.397 . hal-03073901

\section{HAL Id: hal-03073901 https://hal.science/hal-03073901}

Submitted on 16 Dec 2020

HAL is a multi-disciplinary open access archive for the deposit and dissemination of scientific research documents, whether they are published or not. The documents may come from teaching and research institutions in France or abroad, or from public or private research centers.
L'archive ouverte pluridisciplinaire HAL, est destinée au dépôt et à la diffusion de documents scientifiques de niveau recherche, publiés ou non, émanant des établissements d'enseignement et de recherche français ou étrangers, des laboratoires publics ou privés. 


\title{
ICAMEES2018
}

\section{Low Temperature Plasma Nitriding of Low Alloy Steel for the Enhancement of Hardness}

\author{
K. Ram Mohan Rao*al ${ }^{*}$ Corinne Nouveau ${ }^{\mathrm{b}}, \mathrm{K}$. Trinadh ${ }^{\mathrm{a}}$ \\ ${ }^{a 1}$ Department of Chemistry, GITAM Institute of Technology, \\ Gandhi Institute of Technology \& Management, Rushikonda,Visakhapatnam-530045, \\ Andhra Pradesh, India. \\ ${ }^{b}$ Laboratoire Bourguignon des Matériaux et Procédés (LaboMaP), Arts et Métiers Paris Tech de Cluny, Rue \\ Porte de Paris, F-71250, Cluny, France. \\ ${ }^{a}$ Department of Chemistry, GITAM Institute of Science, \\ Gandhi Institute of Technology \& Management, Rushikonda, Visakhapatnam-530045, \\ Andhra Pradesh, India.
}

\begin{abstract}
The present concerns surface modification of low alloy $\mathrm{CrMoV}$ steel by following the route of plasma nitriding for the improvement of hardness. Plasma nitriding was performed at a low temperature of $450{ }^{\circ} \mathrm{C}$. The maximum hardness at this lower temperature was found to be $\sim 1270 \mathrm{H} v$ after nitriding. At $550{ }^{\circ} \mathrm{C}$ though the hardness improvement near the surface region was similar but the core hardness was reduced. XRD studies revealed various nitrides of iron $\left(\gamma^{\prime}\left(\mathrm{Fe}_{4} \mathrm{~N}\right)\right.$ and $\left.\varepsilon\left(\mathrm{Fe}_{2-3} \mathrm{~N}\right)\right)$ with the $\varepsilon$ nitride as the dominant phase. SEM analyses revealed the surface microstructure with almost no white layer. EDS point analyses shown the signature of $\mathrm{N}$ on the surface layer. It has been concluded in this study that the hardness of $90 \mathrm{CrMoV} 8$ steel can be improved significantly even at a low temperature of $450{ }^{\circ} \mathrm{C}$ without any of risk of the loss of core hardness.
\end{abstract}

Keywords: Plasma nitriding; low alloy steel; hardness; X-ray diffraction; case depth

\footnotetext{
${ }^{*}$ al Corresponding author. K. Ram Mohan Rao; Tel.: +09701841790; E-mail address: rammohanrao.k@gmail.com
} 


\section{Introduction}

In recent past, the cutting tool industries were much concerned about the wear and corrosion resistance properties of the tool surface to prolong the service life of the cutting tools. Hard coatings improve the wear and corrosion resistance of cutting tools but the poor adhesion and delamination limit its application [1,2]. Instead of coating surface with the hard layer, if the surface is alloyed the risk of poor adhesion and delamination can be eliminated. Nitriding of the surface was found to be a successful process for the improvement of these properties. It has also been realized that nitriding followed by the coating improves the adhesion of the coated layer [3, 4]. Conventional nitriding uses ammonia with no controllability of the process to achieve the desired properties or the modification of the microstructure. Plasma nitriding as one of the most industrially accepted and eco friendly plasma based processes which has successfully enhanced these properties of steels with a good controllability of the process parameters which enable the surface microstructure modified to desired properties [5-10].

Previously, plasma nitriding of various steels have been studied, however less is known about plasma nitriding of low alloy $90 \mathrm{CrMoV} 8$ steel [11-12]. In this study, attempts had been made to secure a high hardness at a low temperature of $450{ }^{\circ} \mathrm{C}$ and thus eliminating the higher temperature treatment to avoid the risk of distortion of surface or bulk properties. For the sake of comparison nitriding at higher temperature of $550{ }^{\circ} \mathrm{C}$ has also been attempted in this study.

$\mathrm{X}$-ray diffraction, scanning electron microscopy (SEM) and energy dispersive spectroscopic analyses (EDS) have been made to understand the effects on surface microstructure of the post nitrided steel. Following the structural characterization, hardness was measured by Vicker's micro hardness tester. It has been concluded that the low temperature nitriding can also improve the hardness and case depth significantly.

\section{Experimental}

Samples with dimensions $10 \times 10 \times 3 \mathrm{~mm}^{3}$ were cut from a sheet with the composition as given in following Table 1.

Table 1: Chemical composition of CrMoV steel

\begin{tabular}{lccccccc}
\hline Element & $\mathrm{C}$ & $\mathrm{Si}$ & $\mathrm{Mn}$ & $\mathrm{Cr}$ & $\mathrm{Mo}$ & $\mathrm{V}$ & $\mathrm{Fe}$ \\
\hline Wt. (\%) & 0.5 & 1.0 & 0.5 & 8.0 & 1.5 & 0.5 & balance \\
\hline
\end{tabular}


The sample coupons were then subjected to metallographic polishing followed by ultrasonic cleaning in acetone. The cleaned sample coupons were then placed on the sample holder inside the nitriding reactor and evacuated the chamber. Initially, the chamber pressure was kept at $0.5 \mathrm{~Pa}$ and then increased to a fixed working pressure of $500 \mathrm{~Pa}$. The process started with the Ar+ sputtering to clean the surface layer e.g. native oxide layer or other deposits until the desired temperature was attained. Once the nitriding temperature $450{ }^{\circ} \mathrm{C}$ was achieved sputtering was stopped and nitrding cycle initiated. In the glow discharge plasma of $\mathrm{N}_{2}$ and $\mathrm{H}_{2}$ (at the ratio 80:20) nitriding was performed for $6 \mathrm{~h}$ by varying the temperature. The nitriding cycle was closed after nitriding and the cooling cycle in the furnace environment began. All these process cycles were repeated again for nitriding at $550{ }^{\circ} \mathrm{C}$ (higher) temperature for $6 \mathrm{~h}$. The sample holder was biased negatively at $250 \mathrm{~V}$.

Nitrided sample coupons were exposed toscanning electron microscopic(SEM-modelSEM-Jeol JSM5900/EDS) analyses. For the microstructural evaluation samples were exposed to X-ray diffraction(XRD - INEL CPS 120 diffractometer- $\theta / 2 \theta$ configuration)using Co- $k_{\alpha}(0.17932 \mathrm{~nm})$ radiation. Hardness measurements were performed by Vicker's micro hardness tester(LECO MHT210 microhardness tester) at an applied load of $50 \mathrm{~g}$. Each test was repeated ten times and the average of these hardness values was reported.

\section{Results and analyses}

\subsection{Microhardnss measurements}

Micro hardness measurements of the post nitrided samples were taken from the edge towards the bulk of the samples (Fig.1a and b). Fig.1 shows the hardness $v$ s. depth profile of steels nitided at a lower temperature of $450{ }^{\circ} \mathrm{C}$ as well as at the higher temperature of $550{ }^{\circ} \mathrm{C}$. The maximum hardness achieved was $1270 \mathrm{H}_{v}$. This is a $\sim 2$ fold improvement in hardness which is a significantly higher than that shown by untreated steel .

The maximum hardness obtained after nitriding at the lower temperature $450{ }^{\circ} \mathrm{C}$ as well as at the higher temperature $550{ }^{\circ} \mathrm{C}$ was found to be $\sim 1270 \mathrm{H}_{v}$, however the case depth was much shallower at lower temperature nitriding i.e. $\sim 50 \mu \mathrm{m}$. Case depth was considered to be an increase of $10 \%$ over the core hardness. At higher temperature $550{ }^{\circ} \mathrm{C}$ the case depth was found to be $\sim 120 \mu \mathrm{m}$. It should be noted here that this increase in case depth is much more in this case than that obtained at $450{ }^{\circ} \mathrm{C}$ whereas the maximum hardness on the surface remained almost unaltered. A decrease in case depth in the latter case may be attributed to the preferential diffusion of $\mathrm{N}$ than the formation of nitrides in the surface region. The increase in hardness and also the case depth at higher temperature is significant with a marginal loss of core hardness by only $\sim 50 \mathrm{H}_{v}$. Hence, nitriding at a higher 
temperature $550{ }^{\circ} \mathrm{C}$ for a shorter duration of $6 \mathrm{~h}$ may be a good choice for achieving a wider hardened layer if the core loss of $\sim 50 \mathrm{H}_{v}$ is acceptable. This will prolong the life of the tool in the service condition as the wear resistance for a wider case depth is expected to be more.

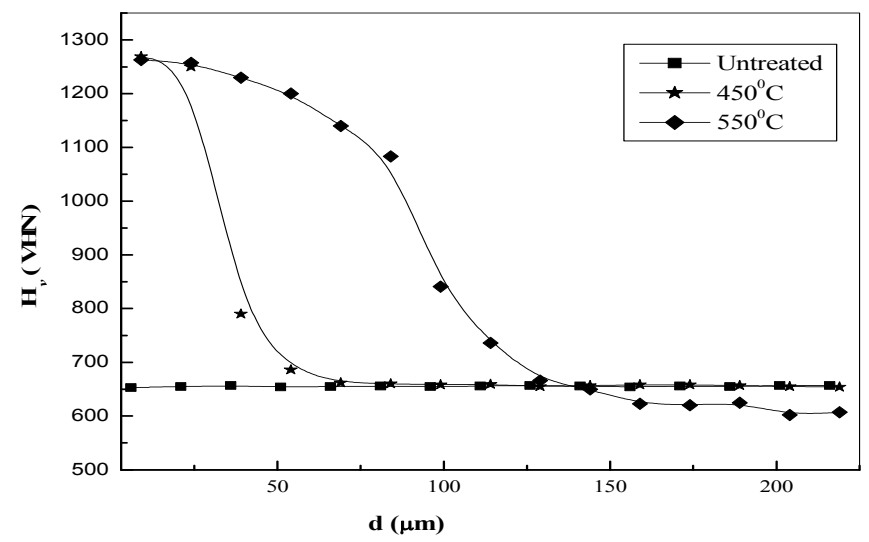

Fig. 1 Microhardness vs. depth profiles of samples treated at $450{ }^{\circ} \mathrm{C}$ and $550{ }^{\circ} \mathrm{C}$ for $6 \mathrm{~h}$.

Plasma nitriding at lower as well as elevated temperatures raises the hardness of $\mathrm{CrMoV}$ steel significantly. Hardness achieved in the present study is much higher than the previously reported hardness values [13-15]. Hardness values achieved by elevated temperature plasma nitriding of $\mathrm{CrMoV}$ steel by other workers are shown in the following Table 1.

Table2. Maximum hardness achieved after plasma nitriding of $\mathrm{CrMoV}$ steels

\begin{tabular}{ccccc}
\hline $\begin{array}{c}\text { Steel type } \\
\text { (martensitic) }\end{array}$ & $\begin{array}{c}\text { Plasma nitriding } \\
\text { at temperature/ } \\
\text { time (h) }\end{array}$ & $\begin{array}{c}\text { Maximum } \\
\text { hardness } \\
\left(\mathbf{H}_{\boldsymbol{v}}\right)\end{array}$ & Year & References \\
\hline $3 \% \mathrm{Cr}-\mathrm{Mo}-\mathrm{V}$ & $\begin{array}{c}538^{\circ} \mathrm{C} / \text { longer } \\
\text { time }\end{array}$ & $\sim 770$ & 2000 & $\begin{array}{c}\text { Rolinski et al. } \\
{[13]}\end{array}$ \\
\hline $3.25 \mathrm{Cr}-\mathrm{Mo}-\mathrm{V}$ & $510^{\circ} \mathrm{C} / 6 \mathrm{~h}$ & 900 & 2004 & Chala et al. [14] \\
\hline $2.95 \% \mathrm{Cr}-\mathrm{Mo}-\mathrm{V}$ & $500^{\circ} \mathrm{C} / 6 \mathrm{~h}$ & 1100 & 2011 & $\begin{array}{c}\text { Pokorný et al. } \\
{[15]}\end{array}$ \\
\hline $8 \% \mathrm{Cr}-\mathrm{Mo}-\mathrm{V}$ & & & & present work \\
$($ this study) & 550 and & 1270 & 2018 & \\
\hline
\end{tabular}


From the above table, it is evident that the plasma nitriding at elevated temperature raises the hardness of CrMoV steel significantly to $1270 \mathrm{H}_{v}$.

The studies so far were concentrated mainly on high temperature nitriding at $500{ }^{\circ} \mathrm{C}$ however, least is known about low temperature nitriding of this steel. In the present study,nitriding was performed at a lower temperature of $450{ }^{\circ} \mathrm{C}$ as well asat the elevated temperature of $550{ }^{\circ} \mathrm{C}$. At this lower temperature also the hardness achieved was $1270 \mathrm{H}_{v}$. This is to be noted here that Pokornýet al. [15] shown an increase in hardness to $1100 \mathrm{H}_{v}$ but at the loss of core hardness $\sim 80 \mathrm{H}_{v}$ whereas in the present study the hardness achieved was more than this hardness without the loss of core hardness. This increase in hardness in the present study could be attributed to the higher concentration of $\mathrm{Cr}$ which is $8 \%$ whereas in the other cases it is around 3\% only. In any case, the present study shows an achievement in hardness much higher than obtained by other workers so far.

Fig. 1 shows that nitriding at lower temperature of $450{ }^{\circ} \mathrm{C}$ increases the maximum hardness $1270 \mathrm{H}_{v}$ which is the same as obtained after nitriding at elevated temperatures as shown by others workers $[16,17]$ and also as shown in in the present study at $550{ }^{\circ} \mathrm{C}$.

\section{$3.2 X$-ray diffraction and SEM analyses}

For the phase evolution nitrided steels treated at various temperatures were subjected to detailed X-ray diffraction (XRD) analyses. Fig. 2 reveals the XRD profiles of samples nitrided at $450{ }^{\circ} \mathrm{C}$ and $550{ }^{\circ} \mathrm{C}$ for $6 \mathrm{~h}$ along with the as-received sample.

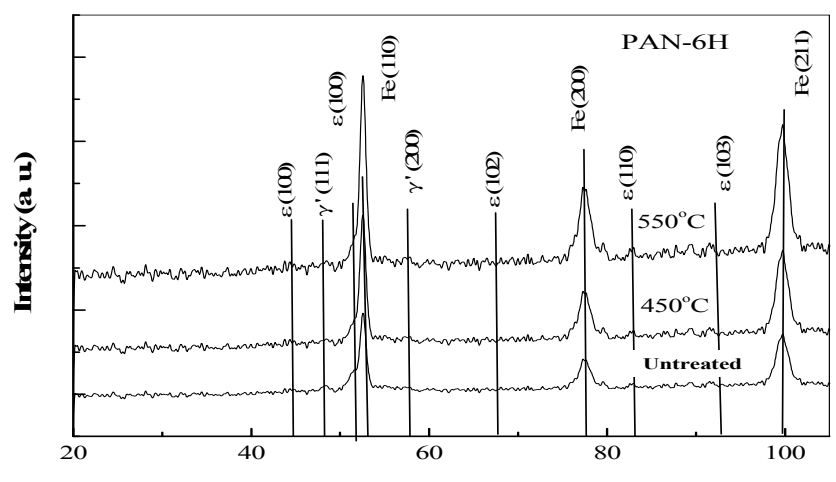

$\mathbf{2 \theta}$

Fig. 2 Bragg-Brentano mode of X-ray diffraction profiles of as-received and nitrided CrMoV steels at variable temperatures $\left(450\right.$ and $\left.550{ }^{\circ} \mathrm{C}\right)$ for a fixed duration of $6 \mathrm{~h}$.

Major peaks of $\alpha$-Fe can be seen with a little distortion may be because of the inclusion of nitrogen in Fe crystal lattice. It is evident that at the lower temperature of $450{ }^{\circ} \mathrm{C}$ the $\alpha$-Fe (110) is slightly expanded. Nitrogen solid solution may increase the stresses which would be beneficial in increasing $\mathrm{t}$ the fatigue resistance. Other phases are predominated by $\varepsilon\left(\mathrm{Fe}_{2-3} \mathrm{~N}\right)$ and $\gamma^{\prime}\left(\mathrm{Fe}_{4} \mathrm{~N}\right)$ phases. 
At $48.23^{\circ}$ a prominent peak of $\gamma^{\prime}(111)$ appears and another peak $\gamma^{\prime}$ (200) with less intensity appears at $54.9^{\circ} . \varepsilon(100), \varepsilon(110)$ and $\varepsilon(103)$ peaks at $44.6^{\circ}, 82.5^{\circ}$ and $91.4^{\circ}$ respectively were grown at lower temperature $450^{\circ} \mathrm{C}$. At this temperature $\mathrm{Fe}(110)$ peak converted to $\varepsilon$ (111) peak as the nitriding time increased. These phases were found to be stable even at higher temperature treatment. The total peak areas of these $\varepsilon$ phases seem to be greater than that of $\gamma^{\prime}$ phase.

Cross sections of the post nitrided samples were polished and etched with the Villela's reagent. Fig. 3 represents SEM and EDS analyses of one of the selected sample treated at $450{ }^{\circ} \mathrm{C}$ for $6 \mathrm{~h}$ revealing the absence of white layer on the surface which is advantageous for the integrity of mechanical properties.
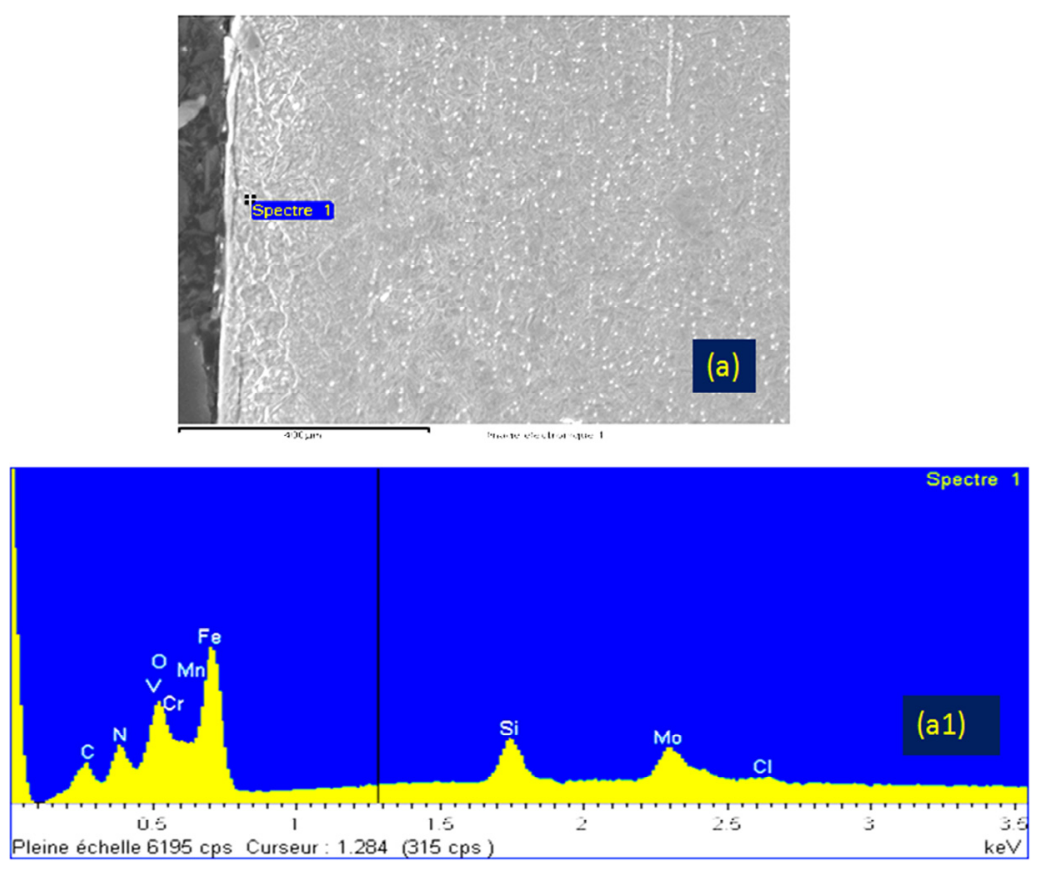

Fig.3 SEM and EDS (a-a1) of CrMoV steel after plasma nitriding at $450{ }^{\circ} \mathrm{C}$ for $6 \mathrm{~h}$.

EDS analyses across the cross section have been done at different points from surface to bulk in all the nitrided steel samples and a representative micrograph and EDS analyses are shown in the above Fig.3. EDS reveals the signature of nitrogen in the nitrided steel along with other elements. It was also found that the concentration of nitrogen decreases from surface to bulk. This is in accordance with the decreasing hardness from the surface to bulk. 


\section{Conclusions}

Plasma nitriding of low alloy $\mathrm{CrMoV}$ steel has shown the improvement of hardness significantly when treated for a shorter duration of $6 \mathrm{~h}$ and at also at a lower temperature of $450{ }^{\circ} \mathrm{C}$. The hardness achieved was $\sim 1270 \mathrm{H}_{v}$. Nitriding at $550{ }^{\circ} \mathrm{C}$ for $6 \mathrm{~h}$ has also increased the hardness to $\sim 1270$ $\mathrm{H}_{v}$ without any significant loss of core hardness. At $550{ }^{\circ} \mathrm{C}$ nitriding, the case depth increased was to $\sim 120 \mu \mathrm{m}$ which is significantly greater than achieved at $450{ }^{\circ} \mathrm{C}$. Thus, nitriding for $6 \mathrm{~h}$ at this temperature is safe for achieving a higher hardness with a wider case depth without affecting much to the loss of core hardness.

\section{Acknowledgements}

The opportunity given to carry out this research and granting the permission to submit the work for the publication by GITAM (Deemed to be University), Visakhapatnam,Andhra Pradesh, India, is gratefully acknowledged. The authors also gratefully acknowledge the group members of ENSAM, Paris Tech., France for their valuable discussion and support to carry out this work.

\section{References}

[1] M. Van Stappen, M. Kerkhofs, L.M. Stals, C. Quaeyhaegens, Surf Coat Tech 629 (1995) 74-75.

[2] C. Nouveau, M.A. Djouadi, R. Marchal, M. Lambertin, Méca \& Indus3 (2002) 333.

[3] M. Bader, H.J. Spies, K. Höck, E. Broszeit, H.J. Schröder, Surf Coat Techno.98(1998) 891.

[4] A. Chala, L.Chekour,C. Nouveau, C. Saied, M.-S Aida,M.-A Djouadi, Surf. Coat. Technol. 200 (2005) 512, (1-4 SPEC. ISS).

[5] E. Menthe, K.T. Rie, J.W. Schultze,Surf. Coat. Technol, 74 (1995) 412-416.

[6] M. Berg, C.V. Budtz-Jorgensen, H. Reitz, K.O. Schweitz, J. Chevallier, P. Kringhoj, Surf. Coat. Technol., 124 (2000) 25-31.

[7] T. Nobuteru,M. Yoshiaki,C. Akiyoshi,H.Yuji,Surf. Coat. Technol.196 (2005) 271-274.

[8] W. Liang,Appl. Surf. Sci.211 (2003) 308-314.

[9] T. Jun, O. Yuusuke, M. Hiroshi, K. Hideyuki, K. Shiomi, T. Imao, J. Mater. Sci. 21(1986) $2493-$ 2496.

[10] J.M. O'brien, D. Goodman: ASM Handbook 4(1991) 420-424.

[11] M.K. Lei, Z.L. Zhang: Surf. Coat. Technol.91 (1997) 25-31.

[12] L. Chekour, C. Nouveau, A. Chala, M.A. Djouadi, Wear, 255 (2003) 1438.

[13] E. Rolinski, F. LeClaire, D. Clubine, G. Sharp, D. Boyerand NotmanR.@ ASM International, JMPEG 9 (2000) 457-462. 
[14] A. Chala, C. Saied , Z. Boumerzoug, L. Chekour, M.S. Aida:Courrier du Savoir-, 2004, Juin $\mathrm{N}^{\circ} 05$, pp.63-68.

[15] Pokorný Zdeněk, Kadlec Jaromír, Hrubý Vojtěch, Pospíchal Miroslav, Dung. Q. Tran, Tereza Mrárázková and Lacslo Fecso:Chem. Listy, 105(2011) 717-720.

[16] J. Takada, Y. Ohizumi, H. Miyamura, H. Kuwahara, S. Kikuchi, I. Tamura, J. Mater. Sci., 21(1986) 2493.

[17] V.I. Dimitrov, J. D’Haen, G. Knuyt, C. Quaeyhaegens, L.N. Stals: Surf. Coat. Technol., 99 (1998) 234. 